\title{
DEVELOPING ENGLISH CONVERSATION MATERIAL FOR ISLAMIC HIGH SCHOOL
}

\author{
Ahmad Thoyyib Shofi \\ thoyyib.shofi@stkipqomaruddin.ac.id \\ STKIP Qomaruddin Gresik
}

\begin{abstract}
Students were very difficult to communicate with other people in English effectively. English was learned as a foreign language (EFL) in this country and Indonesian EFL students rarely speak English in their daily lives. English conversation class was taught by no particular book for both teacher and students. This failure was solved by developing an appropriate teaching material for English conversation class at the tenth grade of Islamic Senior High School, which covered conversational guide selection and the used of instructional media. It also aimed at activating the English conversation class. This study used the Research and Development (R\&D) design. The data were collected through observation, interview, and questioners and analyzed using a guideline analysis, while the data of the students' questioners were analyzed using tally system to find the percentage. The subjects of this study were the students of MA Al Karimi Gresik. There were 90 students of the tenth grade students. The material development started with writing material selected from the syllabus and follows CLT principles. The final product was the conversation material for Islamic Senior High Students. It also contained rubric assessment to record the students speaking progress both psychomotor aspect and affective aspect. The product contained Indonesian translation and no answers. Hopefully, the students could be active in responding the questions at the conversation classroom activity. The researcher wanted the English teacher understand the concept of CLT so that he could become the guide, trainer, advisor, and actor who can control the class.
\end{abstract}

Keywords: Research and Development, English conversation, teaching material, CLT

\section{INTRODUCTION}

People learn language was not only for knowing it but also for using it (Harmer, 2004). So, a communication must be more useful and often used orally. Accordingly, the foreign language learner should be able to communicate English fluently.

Students in Indonesia were hard to communicate with other people in English effectively because English was learned as a foreign language (EFL) in Indonesia and Indonesian EFL students rarely speak English in their daily lives. Therefore, communicative approach was believed to be the most effective approach to build English language environment which the teacher as the facilitator. Teachers develop students' linguistics competence by encouraging them to construct meaning through genuine linguistics interaction with other students and with the teacher (Brown, 2000).
English conversation was an obligation of Indonesian schools to build English language environment in order to prepare their students reaching higher level of education for their life. Continual attention, therefore, must be given to the processes of learning and teaching speaking for EFL students in Indonesia. In Communicative Language Teaching (CLT), students' are learning to communicate so the teachers must keep the good language environment.

Indeed, English Conversation Classes were special classes that focus on the development of English speaking skill. It administered a special language environment where all students were expected to converse in English without being afraid. It was a matter of pleasure that English can be found on language menu in every part of the country and proudly boasts of an important curricular subject. 
As the teacher of English conversation class at Madrasah Aliyah Al Karimi, the researcher considered to improve the students'speaking skill by developing English conversation material for tenth grade students. The English conversation class is focusing on training the tenth grade students to communicate in English intensively, so that they can speak English fluently and accurately.

However, in the process of teaching and learning, both students and teacher, do not use any specific book in learning speaking. Students also do not have other resources for their individual development process. The teacher only used the sources that related to the goal of School Based Curriculum, and then lately it was changed to Curriculum 2013 which has different fundamentals and goals. Therefore, the development of English conversation material was produced based on the fundamentals and goals of curriculum 2013.

Although there were so many textbooks on the market, many teachers still got difficulties in finding books that were entirely suitable for particular groups of students. By some efforts, finally the teacher tried to produce his own materials which were designed based on the need of the students. The materials of the course book were culturally appropriate with the local context and the topics also were very interesting: it was involving the trend topics about politics, culture, and education.

The relevant study that related to this research was the research by Agustiana and Murdibjono (2012). They tried to describe the implementation of teaching English in the conversation class of bilingual program at SMPN Malang by using the theory of Communicative Language Teaching by Richards (2002) who mentioned some communication strategies which were applied to EFL students. The result shown that during the observation process some strategies such as paraphrasing, approximation, using native language, using non-linguistic resource, and asking for help from other people were applied.

Another relevant study that related to this research, Efrizal (2015) developed supplementary teaching speaking materials based on communicative language teaching for second year students of senior high school. The result showed that the draft of supplementary materials development is focused on speaking activity. He developed the supplementary material based on Communicative Language Teaching (CLT) approach and arranged well based on the standard competence and basic competence of the syllabus in senior high school. These supplementary materials included seven chapters and the objective of the topic was stated at the beginning. The topic were chosen under the consideration that related to the students' need and interest and aimed to enrich students' experiences in order to support their daily activities.

In this current study the researcher considered to develop English conversation class material for the tenth grader of MA Al Karimi by conducting Research and Development (R\&D) that involved the theory of Communicative Language Teaching (CLT). The product was in the form of English conversation book for tenth grade students.

\section{Communicative Language Teaching (CLT)}

The emergence of CLT occurred at the time when language teaching was looking for a change (Richards, 2002). Due to the unsatisfactory traditional syllabus that failed to facilitate learners ${ }^{6}$ ability to use language for communication, linguists attempted to design a syllabus to achieve the communicative goals of language teaching (Richards, 2002).

Communicative language teaching could be understood as a set of principles about the goals of language teaching, how learners learn a language, the kinds of classroom activities that best facilitate 
learning, and the roles of teachers and learners in the classroom. CLT set as its goal the teaching of communicative competence. With CLT began a movement away from traditional lesson formats where the focus was on mastery of different items of grammar and practice through controlled activities such as memorization of dialogs and drills, and toward the use of pair work activities, role plays, group work activities and project work.

CLT has been popular and widespread in second and foreign language teaching. It highlighted a radical change of the traditional structured teaching methods which have lived through history. Contrary to the teacher-centered approach, in which teachers are regarded as knowledge givers and learners as receivers, CLT reflects a more social relationship between the teacher and learner.

The learner-centered approach gave students a sense of ownership of their learning and enhances their motivation (Brown, 2000). CLT emphasizes the process of communication and leads learners to different roles from the traditional approach. The role of the learner was negotiator between the self, the learning process, and the object of learning. Learners were actively engaged in negotiating meaning by trying to make themselves understood and in understanding others within the classroom procedures and activities. In this way, they contribute as well as gain in an interdependent way.

Teachers take particular roles in the CLT approach. First, the teacher facilitates the communication process between all participants in the classroom. The teacher was also a co-communicator who engages in communicative activities with the students (Larsen-Freeman, 2000). In addition, the teacher acts as analyst, counselor, and group process manager (Richards \& Rodgers, 1986).
Rather than emphasizing the explicit explanation of grammatical rules, CLT paid less attention to the overt presentation of grammar (Brown, 2000). However, CLT did not exclude grammar. CLT suggests that grammatical structure might be better understood within various functional categories (Brown, 2000). In CLT classes, both accuracy and fluency should be taken into consideration in language teaching, but the aim is to build fluency.

\section{Material Development}

In the teaching process, a teacher needs material that could be used to make his classes more effective and efficient. One of the materials function is to support the objective of the class.

Materials for language learning' will be taken to be anything that can be used to facilitate the learning of a language, including course books, videos, graded readers, flash cards, games, websites and mobile phone interactions, though, inevitably, much of the literature focuses on printed materials. Materials can be informative (informing the learner about the target language), instructional (guiding the learner in practicing the language), experiential (providing the learner with experience of the language in use), eliciting (encouraging the learner to use the language), and exploratory (helping the learner to make discoveries about the language).

Materials development is now not only undertaken by practitioners but is also a field of academic study. As a practical activity it involves the production, evaluation and adaptation of materials. As a field it investigates the principles and procedures of the design, writing, implementation, evaluation and analysis of materials. Ideally, these investigations both inform and are informed by the development and use of materials. This is the case in a number of recent publications 
(e.g. Mukundan 2009a; Mishan \& Chambers 2010; Tomlinson 2010a, 2011a; Harwood 2010a; Tomlinson \& Masuhara 2010, 2012) whose authors are both practicing writers of language-learning materials and academics theorizing about materials development.

The material development is focused on both accuracy and fluency. In accuracy the activity can be such exercises, discrete, form, predictable, close-ended, contrived, correctness, full class work, and open-pair work. In fluency the activities are tasks, integrative, meaning, unpredictable, openended, realistic/life-like, message, closedpair work, and group work (Richards, 2006)

It concludes that the developing English conversation teaching material which consider as most important to accuracy and fluency. This is necessary as a research into Communicative approach or CLT method because of the need to master oral language communication.

\section{METHOD}

\section{Respondents}

This study was conducted in MA Al Karimi. The school was chosen because it was the place where the researcher was teaching English. The chosen school contains 3 classes which each class contains about 30 students. Only a few students mastered English well, most of them have lack vocabulary and grammatical competence. English was taught for $5 \times 45$ minutes per week (Conversation class has $2 \times 45$ and English Lesson has $3 \times 45$ minutes).

\section{Instruments}

The instruments used in this study were interview guide, questionnaire, observation, and the expert judgment. The instruments for collecting the information of the need analyst were interview guide and questionnaire. The interview guide was to interview the teachers of English and the students of MA Al Karimi. The information from the questionnaire are related to the students' speaking habit in English, existence of speaking materials in the school, and the content of speaking materials they need. The instruments for collecting the information about the properness of the product were questionnaire and expert judgment.

\section{Procedures}

The researcher employed an educational research and development proposed by Borg and Gall (1983). This design was usually referred as $R \& D$ cycle. The R\&D (research and Development) cycle consist of research and information collecting, planning, and developing preliminary form of product, preliminary field testing, main product revision, main field testing, and operational product revision. The activities in the proposed model which are good in terms of developing media are simplified into three main steps. Its consists of carrying out need analysis as information collecting activity, developing the product, validating it with the experts and trying it out in the field.

The procedures of developing the instructional materials are the stage that the writer conducted starting from the survey up to the final stage i.e. developing the final product. The steps were on the basis of the development model. Yet researcher tried to use the latest model of developing the educational product in this study which was simpler implemented.

The procedure were assessing the classroom problem, studying recent theories of educational product development, Syllabus Development (Mapping), developing the educational product, reviewing the product closely, validating the product by the expert, trying out the instructional product, and publishing the product.

\section{Data analysis}

This development product title was Joyful English Conversation\| for Islamic 
Senior High School Semester I. The book was developed based on the syllabus of Curriculum 13 which represented on the materials in recent book. There was 34 meeting hour in a semester, and it contained 16 lessons for a semester. Therefore, there was a topic for 2 hour meeting, the last 2 meeting hour was for evaluation. The topics were (1) introduction, (2) appearance, (3) family ties, (4) jobs, (5) time, (6) responsibilities, (7) school, (8) home, (9) health, (9) Facebook, (10) traveling, (11) religion, (12) natural disaster, (14) charities, (15) countries, (16) city services, and etc.

The developed material was not a thick book; it contains not more than 5 pages in one lesson. In each lesson consists of conversation guide, and the vocabulary list. The design of this conversation teaching material was very simple and easy to use. To make it easily in determining the ideas and to communicate them accurately the teaching material was completed with some interesting pictures. The developed material was printed colourfully in standard paper A4 and bonded in saddle stitched.

The students' opinion toward the materials used in English Conversation Classes was gathered by delivering questionnaires (appendix 11) consisted of six question items. The total samples from X-1, X-2, and X-3 were 90 students.

Questionnaire item number 1 indicated students general opinion of the materials used in English Conversation Classes whether they liked it or not. The percentage of the students who very liked the materials was $9.38 \%$.

Questionnaire item number 2 indicated students general opinion of the materials used in English Conversation Classes whether it was interesting or not. The percentage of students who said that the materials are always interesting was $67.69 \%$.
Questionnaire item number 3 indicated students' perception on the benefit of materials taught related to their daily life. The percentage that the materials were very useful was $77.69 \%$.

Questionnaire item number 4 showed students' perception on the benefit of materials taught related to other related subjects at school. The result was most of the students said that it is useful.

Questionnaire item number 5 was an open-ended question about the students ${ }^{6}$ opinion toward the materials that were expected. Most of the students answered that the materials should not only in the class but also an outdoor class or activity. Other students mostly wished that the materials hold in the language laboratory or other places. And some others were satisfied with the materials they already have.

Questionnaire item number 6 was an open-ended question asking what kind of materials that they liked the most or they wished to be used. In grade X, the students said that the materials they liked the most is the materials which is related to science subjects such as biology.

The researcher had been submitted the draft of the developed material to the expert for about a couple of weeks. The researcher got any corrections and advises that the researcher should pay attention on the need. The improvement of this product will be done based on the expert judgement about the product.

After developing the English teaching material on conversation classroom activity, the students complained about the pictures. The researcher needed to revise the pictures on the book, because the book was lack of pictures. To revise the pictures the researcher need to communicate with the book designer. Finally the result was great; the designer can illustrate some interesting pictures that support the topics.

Overall, the students showed positive attitudes toward the developed material, agreed that they enjoyed teaching-learning 
activities and would use the developed material in the class and outside the class. This result was similar to the finding of Widiyati (2012), she observed a different group of SMA 8 students ' activities in conversation class and found the activities were valuable to the students. Although the study was only involved a small number of students in a short period of time, the result showed that the developed material can be useful and helpful for the learning of EFL.

\section{FINDINGS AND DISCUSSION}

Basically this research was conducted to develop teaching materials for English conversation class grade ten at MA Al Karimi. The developed teaching material aimed to activate the conversation classroom activity, and to enhance the students idea in the topic discussed. The design of conducting the research was research and development, known as R \& D.

Based on the goal the study, the researcher did need assessment toward all aspect that support the students' English competence. The need assessment was conducted by interviewing students and giving those questionnaires to specify which parts that were needed to be developed.

The results suggested that although the practical issues of explanation and implementation have often been dealt with, those issues that concern the theoretical aspects of Communicative Language Teaching (CLT) was superficially addressed. The different approaches to communication and traditional approach become clear when one examines the textbooks. There was a marked difference between low level and higher level students toward the textbooks. The textbooks at the higher end of the line not only provide a wide range of communicative-based activities for practice, but they also contextualize it.
The textbooks either provided Indonesian equivalent and a lot of questions adopted from American or British English that embed the real foreign language in a context, which Indonesian students were strange with those languages. This contextualization was found in all the activities for the present progressive aspect and indeed throughout most of the activities in the textbooks. However, these high-rated textbooks were not those consistently selected by language teachers.

This English Conversation textbook considered that speaking was as the easiest skill since one can use the body language, demonstration, repetition, and various other strategies to make oneself understood. In Indonesian school context, the students must achieve psychomotoric aspect in learning English conversation. By all the topics on developed teaching materials the psychomotoric aspect could be easily examined by the teacher.

Else, the principle of CLT which were useful for this developed teaching material was that the principle of questioning that can generate to inquiry and the community learning task which could be implemented on peer work and group work/discussion.

\section{CONCLUSION}

After doing along process of research and development; writing the teaching materials, reviewing literature, revising, validating to the experts towards the CLT approach implemented to the developed teaching materials, and revised again, finally the purposed developed teaching material can produce 16 lessons and their assessment rubrics.

The strengths of this developed conversation teaching material was on the content, the features, and the effectiveness of teaching learning activity. On the content, there were some interesting topics and in the end of the lesson there was assessment rubric. By applying the material, the students hopefully could be 
critical on the conversation classroom activity, because there were not any answers on the conversation guide. The features of the developed material was really interesting because it contained some relevant pictures with the topics, the pictures could successfully stimulate the students interest so that they became very active to join the conversation class. Also, this book contained vocabulary list, blank note, scoring rubric, and self-assessment which were very useful in English conversation class because some students do not bring dictionaries. The scoring rubric and self-assessment were employed to record the students 'progress.

\section{REFERENCES}

De Gruyter, Mouton. 2008. Hand Book of Communication Competence. Göttingen: Hubert \& Co.

Efrizal, Dedi. 2015. Developing Supplementary Teaching Speaking Materials Based On Communicative Language Teachingfor Second Year Students Of Senior High School At An-Nur Islamic Boarding School Of Malang.

[http://ejournal.iainbengkulu.ac.id/i ndex.php/linguists/article/view/99]. Accessed March 29, 2018.

Harmer, J. 2004.Learning ESL Composition. Rowley, M.A: Newbury House.

Latief, M. A. 2011. Research Methods on Language Learning an Introduction. Malang: Universitas Negeri Malang (UM Press).

Maxom, Michelle. 2009. Teaching English as a Foreign English for Dummies. John Wiley \& Sons, Ltd, publications.

Richards, Jack. C. 2002. Curriculum Development in Language Teaching. Cambridge: Cambridge University Press.

Richards, Jack. C. 2006. Communicative Language Teaching Today. Cambridge: Cambridge University Press

Tomlinson, B. 2003.Developing Materials for Language Teaching: Electronic Material for Language Teaching. London: British Library. 